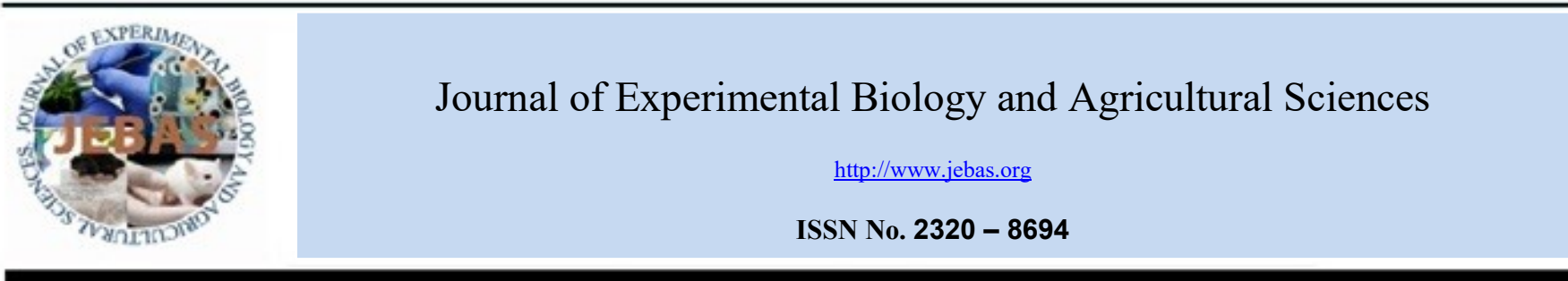

\title{
WEED COMMUNITY ASSESSMENT AND RESPONSE TO SMOTHER CROPPING STRATEGIES AT GEORGE, SOUTH AFRICA
}

\begin{abstract}
Michael Ignatius Ferreira
Directorate: Plant Sciences, Programme: Research and Technology, Development, Western Cape Department of Agriculture, Private Bag X1, Elsenburg, 7607 South
\end{abstract} Africa

Received - May 12, 2020; Revision - June 30, 2020; Accepted - August 23, 2020

Available Online - August 25, 2020

DOI: http://dx.doi.org/10.18006/2020.8(4).369.380

\section{KEYWORDS \\ Biomass mulch \\ Brush cutting \\ Flail heads \\ Rotarary mowing \\ Weed suppression \\ Zero-tillage}

\section{* Corresponding author}

E-mail: mikefe@elsenburg.com (Michael Ignatius Ferreira)

Peer review under responsibility of Journal of Experimental Biology and Agricultural Sciences.

Production and Hosting by Horizon Publisher India [HPI] (http://www.horizonpublisherindia.in/).

All rights reserved.

\begin{abstract}
Weeds are one of the major constraints to crop cultivation that can affect crop yield based on their species composition and density. A field trial was initiated to assess the weed community composition and evaluate eco-friendly weed suppressive strategies. The main objective of this study was first to assess the floristic composition to determine pre-existing weed abundance and secondly to determine the response in terms of relative weed density subsequent to treatments. The identification of weeds occurred at each sampling point and the number of individuals of all species recorded separately. This showed the distribution of species among 19 plant families. Annual bluegrass (Pоа аппиа L.) ranked as the most abundant winter weed with an index value of 34.9. Yellow nut sedge (Cyperus esculentus L.) ranked as the most abundant summer weed with a value of 74.8. At final weed assessment, scarlet pimpernel (Anagallis arvensis L.) was the most important winter weed across all treatments and recorded relative densities above $25 \%$ in weed communities. The most important weed in terms of relative summer weed density was yellow nut sedge (C. esculentes), which maintained a presence of $14.4 \%$ or greater, across all treatments. Persistent and troublesome weed communities may be managed non-chemically by smother cropping strategies by integrating zero-tillage; legume-based cropping mixtures, brush cutting, and rotary mowing with flail heads to produce biomass mulch. This could promote more desirable weed communities and suppress noxious weeds such as yellow nut sedge in the context of local conditions.
\end{abstract}

All the articles published by Journal of Experimental Biology and Agricultural Sciences are licensed under a Creative Commons Attribution-NonCommercial 4.0 International License Based on a work at www.jebas.org.

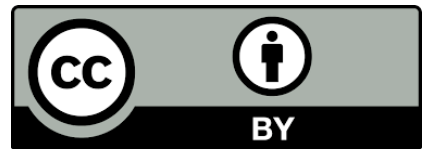




\section{Introduction}

Despite the application of herbicides and other control measures, weeds remain one of the main issues in cropping systems, as they are responsible for significant losses in crop yield and quality (Campiglia et al., 2018) and may interfere with crop harvest and agricultural chemical application (McCully et al., 1991). Weeds are one of the major production constraints to crop cultivation that can affect crop yield based on their species composition and density (Kropff et al., 1992) and compete with plants for water, nutrients, light, space and also host pests and diseases that can affect the crop (McCully et al., 1991).

On the positive side, it has been proven that weed communities can promote soil enrichment, prevent soil erosion and mechanical compaction and act as a source of organic matter and nitrogen (Juarez-Escario et al., 2017) and be natural antagonists of pests and diseases (Cicuzza et al., 2012). Moreover, weed communities contribute to increasing the biodiversity of agroecosystems (Mas et al., 2007) and provide ecosystem services, such as the conservation of pollinators (Garcia \& Mifiarro, 2014).

Previous studies indicated that management practices do affect weed communities in terms of composition, diversity (JuarezEscario et al., 2017), and abundance of individual species (Ferrara et al., 2015). The presence of each weed population in an arable field is the result of ecological reactions to previous management practices, soil characteristics of the site, and the regional climate (Andersson \& Milberg, 1998). Weed populations also reflect the effects of local weather conditions on recruitment, survival and competitive ability (Milberg et al., 2000).

Agricultural management actions, as well as local environmental conditions, act as filters, and thus determine which species of weeds can survive in a given agro-ecosystem (Navas, 2012). For example, agricultural intensification is characterized by increased resource availability and an increased frequency and/or intensity of disturbance experienced by weeds. These conditions select for traits that allow weeds to exploit available resources to maximize growth and reproductive output in a short timeframe between disturbances (Garnier \& Nava, 2012). Moreover, crops and management practices provide different weed growth conditions (Doucet et al., 1999) and therefore act as a filter which determines weed community assembly according to their functional characteristics, such as winter or summer growing season and annual or perennial growth habit (Gaba et al., 2017). For example, for most troublesome weed, planting dates, cropping sequences, brush cutting and rotary mowing with flail heads were utilized to specifically target competitive effects at different stages of nut sedge growth and underground storage capacity of carbohydrate reserves (Wedryk \& Cardina, 2012).
Suppressing troublesome annual weeds could be effectively achieved by smother crops which have the potential for rapid biomass production (Wedryk \& Cardina, 2012). Smother crops are living plants growing in a pure stand or mixtures of species to reduce the germination, growth and reproduction of undesirable plants through resource competition (Wedryk \& Cardina, 2012). Additionally, the use of a smother crop mixture may be more effective at suppression than individual species due to occupation of different above and belowground niches by the different species (Linares et al., 2008). Cropping mixtures containing legumes with high levels of allelochemicals seem well-suited for plant residuemediated weed suppression (Ferreira \& Reinhardt, 2010). Also, smother crop species that differ in their adaptation might compete most effectively at different stages in the life cycle of weeds (Wedryk \& Cardina, 2012).

Smother crops can be terminated by mowing with a brush cutter, followed by rotary mowing with flail heads to produce a mulch that can be utilized for weed suppression in crop rotations (Wedryk \& Cardina, 2012). Furthermore, brush cutting and rotary mowing with flail heads of high biomass producing smother cropping mixtures are non-chemical agricultural practices. Besides, smother cropping practices and crop sequencing should include as much variety as possible to disrupt weed species' emergence, life cycles and seed production. These practices in combination with initial limited herbicide applications were implemented in an integrated way at George to evaluate the effects on the relative density of weed species.

Upon a request by the Directorate: Farmer Support and Development, Western Cape Department of Agriculture, a field trial was initiated to assess the weed community composition and evaluate eco-friendly weed suppressive strategies on the vegetable farm of the Department of Correctional Services at George (33.979202, 22.446229), South Africa. It was hypothesized that weed growth and development would be impacted effectively by high biomass producing winter smother cropping in a zero-tillage system, terminated by brush cutting, rotary mowing with flail heads and mulching and subsequent planting of a summer smother crop. It was postulated that leguminous smother cropping mixtures would produce the greatest amount of biomass and provide the greatest weed suppression by imposing strong filters on weeds. Strong filters were also expected to select for specific functional types of weeds, i.e. those possessing the requisite traits to survive the filters and would include species with low plant height or a prostrate growth habit that can grow at reduced light intensity due to shading by tall crops or thick mulches (MacLaren et al., 2019). In this process, it would reduce the relative density of more noxious weeds such as yellow nut sedge (C. esculentus $\mathrm{L}$.).

Since there is no detailed information on the residual weed community at George, the main objective of this study was firstly 
to assess the floristic composition to determine pre-existing weed abundance. Secondly, the aim was to measure the response in terms of relative weed density after treatments with leguminous smother cropping mixtures, planted sequentially and integrated with zero-tillage, brush cutting and rotary mowing with flail heads to produce a biomass mulch.

\section{Materials and Methods}

A field experiment was conducted on the vegetable farm of the Department of Correctional Services at George, South Africa. Preceding the field experiment, two assessments for winter and summer weeds respectively were conducted during the first weeks of September and March. At those stages, all annual weeds normally reach physiological maturity which enables identification. These assessments took place from 2014 - 2017 and served as a baseline study utilized to evaluate weed community response to treatments in terms of individual species' final density.

\subsection{Study Site and Climate}

The climate of this area falls within the oceanic climatic zone with average long term annual precipitation of $715 \mathrm{~mm}$, spread fairly evenly over months, but with an increase in late winter and spring. Annual average daily maximum and minimum temperatures range between $26^{\circ} \mathrm{C}$ and $8^{\circ} \mathrm{C}$ respectively. Since distinct seasons in terms of temperature and day length manifests in either winter or summer growing seasons for annual weeds with none occurring in both seasons, these were recorded as such and all data handled separately.

The soil type at this locality was classified as a fine, sandy-loam duplex or podzol (Soil Classification Working Group, 1991; Swanepoel et al., 2015), otherwise known as Alfisols (Soil Survey Staff, 2003). This soil is moderately well-drained with $\mathrm{pH}$ of 5.7, organic matter content $3.1 \%$ and available $\mathrm{P}$ and $\mathrm{K}$ were 19.6 and $54.3 \mathrm{mg} \mathrm{kg}^{-1}$ soil, respectively (Soil Science Laboratory, Western
Cape Department of Agriculture). The site was a 30 years old conventionally managed vegetable field before the experiment commenced.

\subsection{Field preparation}

Subsequent to the initial weed assessments, the entire area was prepared by a mouldboard plough followed by a Kongskilde tiller to obtain a fine seedbed. Hereafter and for the duration of the fouryear experiment, it was treated as a zero-till experiment with less than $30 \%$ soil disturbance. Only at seeding with an Aichison no-till drilling machine did minimal soil disturbance occur. Following seed drilling and to ensure good soil-seed contact, all plots were finished off by a roller. Throughout the experiment, limited tractor traffic across the area included herbicide application, brush cutting, and rotary mowing with flail heads.

\subsection{Agrochemical applications}

To reduce the overwhelmingly heavy infestation of nut sedge to manageable levels, an application of halosulfuron (200 $\mathrm{g}$ a.i ha $\left.{ }^{-1}\right)$ was made in the last week of March in each of the second and third years of the experiment. Similarly, for general weed control, annual pre-plant applications of both glyphosate $\left(450 \mathrm{~g} \mathrm{a.i} \mathrm{ha}^{-1}\right)$ in the second week of April and paraquat/diquat (200 $\left.\mathrm{g} \mathrm{a.i} \mathrm{ha}^{-1}\right)$ in the third week of October took place. The experiment was otherwise handled zero-till and managed without the use of pesticides or fertilizers.

\subsection{Field experiment and Treatments}

Treatments were arranged in a randomized block design with treatments of winter smother crops in mixtures with legumes (Table 1). Four replicates were utilized and the dimensions of individual plots were $30 \mathrm{~m} \mathrm{X} 4 \mathrm{~m}$. The untreated control plots remained undisturbed all year round except for also being subjected to brush cutting in March and September. This was done

Table 1 Summary of cropping sequences utilized at George subsequent to the preceding weed assessment

\begin{tabular}{|cccccccccc}
\hline \multicolumn{2}{c}{2014} & \multicolumn{2}{c}{2015} & & & 2016 & & 2017 & \\
Treatment & Winter & Summer & Winter & Summer & Winter & Summer & Winter & Summer \\
\hline SCB & Untreated & Untreated & Saia oats & Teff grass & Cereal rye & Teff grass & Braco mustard+Vetch & Teff grass \\
\hline CSC & Untreated & Untreated & Cereal rye & Teff grass & Saia oats & Teff grass & Cereal rye+Vetch & Teff grass \\
\hline SSB & Untreated & Untreated & Saia oats+Lupine & Teff grass & Cereal rye+Serradella & Teff grass & Braco mustard & Teff grass \\
\hline CBS & Untreated & Untreated & Cereal rye+Serradella & Teff grass & Braco mustard & Teff grass & Saia oats+Lupine & Teff grass \\
\hline BSC & Untreated & Untreated & Braco mustard & Teff grass & Saia oats+Lupine & Teff grass & Cereal rye+Serradella & Teff grass \\
\hline SBC & Untreated & Untreated & Saia oats+Serradella & Teff grass & Braco mustard+Lupine & Teff grass & Cereal rye+Lupine & Teff grass \\
\hline BCB & Untreated & Untreated & Braco mustard+Lupine & Teff grass & Cereal rye+Vetch & Teff grass & Braco mustard+Lupine & Teff grass \\
\hline C & Untreated & Untreated & Control & Control & Control & Control & Control & Control \\
\hline
\end{tabular}

Journal of Experimental Biology and Agricultural Sciences

http://www.jebas.org 
to limit weed seed production and secondary weed infestations. Winter smother crop mixtures were always seeded during the last week of April before the emergence of winter weeds. Planting of teff grass always occurred during the third week of November when the long term average daily minimum temperature reached $15{ }^{\circ} \mathrm{C}$ in this area. Crop rotations and sequencing are listed in Table 1. Treatment SCB for example, comprised of the following production practices utilized from Year 2 onwards: herbicide applications - saia oats - brush cutting - rotary mowing - herbicide application - teff grass - rotary mowing (Year 2); herbicide applications - cereal rye - brush cutting - rotary mowing - herbicide application - teff grass - rotary mowing (Year 3); Braco mustard+vetch - brush cutting - rotary mowing - teff grass - rotary mowing (Year 4) (Table 1).

The winter cover crop planting date was chosen because it fits in between the senescence of yellow nut sedge and annual summer weeds and the emergence of most annual winter weeds. Similarly, summer planting of teff grass took place after the senescence of annual winter weeds and before the emergence of yellow nut sedge and most summer weeds. Both planting dates were also scheduled to take place three weeks after field drying of crop residues following rotary mowing with flail heads. These same plots were planted each summer to a pure stand of teff grass at a seeding density which was increased by $20 \%$ from the recommended rate to increase weed suppressive ability. It was observed by Wedryk \& Cardina (2012) that the use of crops that have high biomass production rates when nut sedge tuber reserves are low, may be an effective strategy for suppressing this particular weed. As a summer smother crop species adapted to warmer temperatures, teff grass is capable of forming competitive stands with high biomass production and strong plant interference when yellow nut sedge is actively growing.

Brush cutting of all smother crops was performed during the first week of September at a growth stage when optimum plant biomass production was achieved. This period was chosen to prevent crop seed shedding close to maturity. Rotary mowing with flail heads followed a month later in October due to higher humidity and slower drying of crop residues during September. These practices extended the period of weed suppression with thick biomass mulches. Teff grass was not brush cut, but the only rotary mowed with flail heads in the third week of March. The practice of rotary mowing with flail heads was utilized to chop up crop residues into finer particles to ensure an even spread of plant biomass and speed up its decomposition. Thus, the least amount of plant residue interference during seed drilling was experienced. Also, since rotary mowing with flail heads speeded up the decomposition process, nutrient cycling provided sufficient nutrients for crop growth and biomass production over the entire trial period.
The winter smother crops utilized were saia oats (Avena strigosa Schreb.), lupine (Lupinus albus L.), cereal rye (Secale cereale L.), Braco mustard (Sinapis alba L.), vetch (Vicia spp.) and pink serradella (Ornithopus sativus Brot.). Teff grass (Eragrostis tef (Zucc.) Trotter) was planted as a summer mono-crop. Smother crop mixture composition and seeding rates are listed in Table 2.

Table 2 Composition of smother crop mixtures and seeding rates utilized in cropping sequences at George

\begin{tabular}{|c|}
\hline Cereal rye $50 \mathrm{~kg} \mathrm{ha}^{-1}$ \\
\hline Saia oats $65 \mathrm{~kg} \mathrm{ha}^{-1}$ \\
\hline Braco mustard $5 \mathrm{~kg} \mathrm{ha}^{-1}$ \\
\hline Braco mustard $2 \mathrm{~kg} \mathrm{ha}^{-1}+$ Lupine $66 \mathrm{~kg} \mathrm{ha}^{-1}$ \\
\hline Braco mustard $2 \mathrm{~kg} \mathrm{ha}^{-1}+$ Vetch $14 \mathrm{~kg} \mathrm{ha}^{-1}$ \\
\hline Cereal rye $22 \mathrm{~kg} \mathrm{ha}^{-1}+$ Lupine $66 \mathrm{~kg} \mathrm{ha}^{-1}$ \\
\hline Cereal rye $22 \mathrm{~kg} \mathrm{ha}^{-1}+$ Serradella $17 \mathrm{~kg} \mathrm{ha}^{-1}$ \\
\hline Cereal rye $22 \mathrm{~kg} \mathrm{ha}^{-1}+$ Vetch $14 \mathrm{~kg} \mathrm{ha}^{-1}$ \\
\hline Saia oats $29 \mathrm{~kg} \mathrm{ha}^{-1}+$ Lupine $66 \mathrm{~kg} \mathrm{ha}^{-1}$ \\
\hline Saia oats $29 \mathrm{~kg} \mathrm{ha}^{-1}+$ Serradella $17 \mathrm{~kg} \mathrm{ha}^{-1}$ \\
\hline Teff grass $18 \mathrm{~kg} \mathrm{ha}^{-1}$ \\
\hline
\end{tabular}

\subsection{Data analyses}

In each plot, weeds were quantified based on an adapted method described by McCully et al. (1991). Assessments were conducted over the trial area by placing forty quadrants of $0.25 \mathrm{~m}^{2}$ each in an inverted $\mathrm{W}$ pattern. Ten quadrants were placed equidistantly along each transect. After identification at each sampling point, the number of individuals of all weed species within a $0.25 \mathrm{~m}^{2}$ quadrat $(0.5 \mathrm{~m} \times 0.5 \mathrm{~m})$, was recorded separately.

The composition of the weed flora was analyzed according to the methods of McCully et al. (1991) and Shrestha et al. (2001) by calculating the relative abundance of each species across the trial area to overcome the patchy nature of weed communities. This value has no units (McCully et al., 1991) and therefore is an index (Shrestha et al., 2001) which is used to rank the contribution of individual species in the weed community and to compare the contribution of groups of species as follows:

Relative abundance $=($ relative frequency + relative density $)$

Where relative frequency $=$ the proportion of quadrats in which the species was the present per plot, divided by the total frequency of all species;

And relative density $=$ number of plants for a given weed species within the quadrats per plot, divided by the total number of weeds within quadrats over the entire sampling area. 
Moeini et al. (2008) modified this method to include relative mean weed density for species $\mathrm{k}\left(\mathrm{RD}_{\mathrm{k}}\right)$ :

$\mathrm{RD}_{\mathrm{k}}=\frac{\text { Mean relative density value of species } \mathrm{k}}{\text { Sum of mean relative density values for all species }} \times 100$

This indicates the contribution of each species to the weed community across treatments, expressed proportionally as a percentage. Henceforth, this method was utilized for comparing final relative weed densities across treatments.

\section{Results}

\subsection{Preceding weed assessment}

Following the initial assessment, it was evident that the residual weed community consists of varying plant families and annual species occurring in either winter or summer (Table 3). This was also manifested in weed species composition, frequency, density and relative abundance (Tables 4 and 5).

Weeds were distributed among 19 plant families with the most dominant being the Asteraceae with 8 species (Table 3). This was followed by another important plant family in terms of field taxa, namely Poaceae, which was represented by five species. Three species each were observed for Brassicaceae, Caryophyllaceae, Polygonaceae, and two species were recorded for both the Amaranthaceae and Solanaceae (Table 3). All of these plant families are species-rich, many of which are weeds. At this locality with an oceanic climate and coupled to constant soil disturbances and irrigation during drier periods, soil and environmental conditions contribute a substantial number of species to the total weed population with an even occurrence of weeds in winter and summer growing seasons.

These 19 plant families comprised of a total of 38 different annual weed species. Of these, 32 species were dicotyledons (84.2\%), monocotyledons contained five species (13.2\%) and Cyperaceae contributed one species (2.6\%). The distribution of species across all 19 plant families was disproportionate since $57.9 \%$ of the species were contributed by only five families, while the remaining $42.1 \%$ were represented by 14 families. Of these, 12 families were represented by only a single species (Table 3). Overall, four species were native, while 34 were alien. Native weed species included Cape marigold (Arctotheca calendula (L.) Levyns), Cape cerastium (Cerastuim capense Sond.), devil's thorn (Emex australis Steinh.), and Cape sorrel (Oxalis pes-caprae L.). An equivalent number of 19 summer and 19 winter annual weeds were recorded. Due to the distinct differentiation of weed communities adapted to seasonal growing conditions, data for winter or summer weeds were handled separately and presented as such (Table 3).

\subsection{Winter weed abundance}

The most common and most serious winter weed was annual bluegrass (Poa annua L.) with a frequency of $8.4 \%$. Additional winter weeds which occurred within the quadrats in frequencies greater than 6 percent, included chickweed (Stellaria media (L.) Vill.) wall fumitory (Fumaria muralis W.D.J. Koch.), wild radish (Raphanus raphanistrum L.), corn spurry (Spergula arvensis L.) and devil's thorn (E. australis Steinh.) (Table 4).

Annual blue grass ( $P$. annua L.) ranked as the most abundant winter weed with a value of 34.9 and a relative density of $26.6 \%$. Chickweed (S. media (L.) Vill.), wall fumitory (F. muralis W.D.J. Koch.), wild radish ( $R$. raphanistrum L.), corn spurry (S. arvensis L.) and devil's thorn (E. australis Steinh.) all had relative densities above $5 \%$ (Table 4). These were also the highest-ranking winter weeds in terms of relative abundance with values ranging from $11.8-18.1$. Frequencies of the remaining 13 weeds ranged from $1.0 \%$ to $5.6 \%$ with corresponding relative densities ranging from $0.5 \%$ to $4.4 \%$ (Table 4 ).

\subsection{Summer weed abundance}

Yellow nut sedge (C. esculentus L.) ranked as the most abundant summer weed (Table 5). It was the most common and most serious summer weed with the greatest frequency of $8.8 \%$. Other summer weeds which occurred within the quadrates in frequencies greater than $6 \%$, included gallant soldier (Galinsoga parviflora Cav.), prostrate knotweed (Polygonum aviculare L.), flax-leaf fleabane (Conyza bonariensis (L.) Cronq.), Cape pig weed (A. hybridus L.), sweet signal grass (Brachiaria eruciformis (Sm.) Griseb.), white goose foot (Chenopodium album L.), and Paterson's curse (Echium plantagineum L.). These were also the highest-ranking summer weeds in terms of relative abundance, with values ranging between 8.2 and 10.7 (Table 5). Frequencies of the 11 remaining summer weeds ranged from $1.1 \%$ to $5.5 \%$ (Table 5).

\subsection{Final winter weed density}

At final weed assessment, scarlet pimpernel (A. arvensis L.) was the most important winter weed across all treatments and recorded relative densities above $25 \%$ in all of these weed communities (Table 6). This value dropped to $15.1 \%$ in the untreated control and was most probably due to inter-species competition and less shading in the untreated plots. Normally, in those situations more radiation is prevalent, benefitting other weed species and increasing their competitive effects.

The second most important weed at final weed assessment in terms of relative winter weed density was annual blue grass ( $P$. annua L.), which maintained a presence of $8 \%$ or greater, across all treatments. For the untreated control, this dropped to $4.6 \%$ of the weed community (Table 6), most likely due to inter-species competition. In treatment SCB, this increased to $21 \%$, probably due to wetter soil conditions in those plots. The species with the third-highest relative winter weed density of $4.4 \%$ or higher, across all treatments, was corn spurry (S. arvensis L.). This increased to above $20 \%$ (Table 6 ) in both treatments SSB and CBS. 
Table 3 Botanical name, plant family, common name and growing season of annual weed flora observed at George during a preceding assessment

\begin{tabular}{|c|c|c|c|}
\hline Botanical name & Plant Family & Common name & Growing season \\
\hline Amaranthus hybridus L. & Amaranthaceae & Cape pig weed & summer \\
\hline Arctotheca calendula (L.) Levyns & Asteraceae & Cape marigold & winter \\
\hline Anagallis arvensis $\mathrm{L}$. & Primulaceae & scarlet pimpernel & winter \\
\hline Bidens pilosa $\mathrm{L}$. & Asteraceae & common blackjack & summer \\
\hline Brachiaria eruciformis (Sm.) Griseb. & Poaceae & sweet signal grass & summer \\
\hline Capsella bursa-pastoris (L.) Medik. & Brassicaceae & shepherd's purse & winter \\
\hline Cerastuim capense Sond. & Caryophyllaceae & Cape cerastium & winter \\
\hline Chenopodium album $\mathrm{L}$. & Amaranthaceae & white goose foot & summer \\
\hline Conyza bonariensis (L.) Cronq. & Asteraceae & flax-leaf fleabane & summer \\
\hline Coronopus didymus (L.) Sm. & Brassicaceae & twin cress & winter \\
\hline Cyperus esculentus $\mathrm{L}$. & Cyperaceae & yellow nut sedge & summer \\
\hline Datura stramonium L. & Solanaceae & thorn apple & summer \\
\hline Digitaria sanguinalis (L.) Scop. & Poaceae & large crabgrass & summer \\
\hline Echium plantagineum $\mathrm{L}$. & Boraginaceae & Paterson's curse & summer \\
\hline Eleusine coracana (L.) Gaertn. & Poaceae & goose grass & summer \\
\hline Emex australis Steinh. & Polygonaceae & devil's thorn & winter \\
\hline Erodium moschatum (L.)L'Hér. & Geraniaceae & musk heron's bill & winter \\
\hline Fumaria muralis W.D.J. Koch. & Papaveraceae & wall fumitory & winter \\
\hline Galinsoga parviflora Cav. & Asteraceae & gallant soldier & summer \\
\hline Gnaphalium subfalcatum Cabrera. & Asteraceae & Gnaphalium & summer \\
\hline Hypochaeris glabra $\mathrm{L}$. & Asteraceae & smooth cat's ear & winter \\
\hline Lactuca serriola $\mathrm{L}$. & Asteraceae & milk thistle & summer \\
\hline Lamium amplexicaule L. & Lamiaceae & common henbit & winter \\
\hline Lolium multiflorum Lam. & Poaceae & Italian ryegrass & winter \\
\hline Malva parviflora $\mathrm{L}$. & Malvaceae & little mallow & winter \\
\hline Nicandra physalodes (L.) Gaertn. & Solanaceae & apple-of-Peru & summer \\
\hline Oenothera parodiana Munz. subsp. parodiana & Onagraceae & evening primrose & summer \\
\hline Oxalis pes-caprae $\mathrm{L}$. & Oxalidaceae & Cape sorrel & winter \\
\hline Plantago lanceolata $\mathrm{L}$. & Plantaginaceae & ribwort plantain & winter \\
\hline Pоа аппиа $\mathrm{L}$. & Poaceae & annual blue grass & winter \\
\hline Polygonum aviculare $\mathrm{L}$. & Polygonaceae & prostrate knotweed & summer \\
\hline Portulaca oleracea $\mathrm{L}$. & Portulacaceae & common purslane & summer \\
\hline Raphanus raphanistrum $\mathrm{L}$. & Brassicaceae & wild radish & winter \\
\hline Rumex crispus $\mathrm{L}$. & Polygonaceae & curly dock & winter \\
\hline Sonchus asper (L.) Hill & Asteraceae & spiny sowthistle & summer \\
\hline Spergula arvensis L. & Caryophyllaceae & corn spurry & winter \\
\hline Stellaria media (L.) Vill. & Caryophyllaceae & chickweed & winter \\
\hline Tribulus terrestris L. & Zygophyllaceae & devil's-thorn & summer \\
\hline
\end{tabular}

Journal of Experimental Biology and Agricultural Sciences http://www.jebas.org 
Table 4 Botanical name, frequency, relative density and relative abundance of annual winter weeds observed at George during a preceding assessment

\begin{tabular}{|c|c|c|c|}
\hline & Frequency & Relative & Relative \\
\hline Botanical name & $\%$ & density $\%$ & abundance \\
\hline Poа аппиа $\mathrm{L}$. & 8.4 & 26.6 & 34.9 \\
\hline Stellaria media (L.) Vill. & 6.6 & 11.5 & 18.1 \\
\hline Fumaria muralis W.D.J. Koch. & 5.9 & 9.5 & 15.4 \\
\hline Raphanus raphanistrum $\mathrm{L}$. & 7.0 & 7.8 & 14.7 \\
\hline Arctotheca calendula (L.) Levyns & 5.6 & 7.9 & 13.5 \\
\hline Spergula arvensis $\mathrm{L}$. & 6.3 & 6.4 & 12.7 \\
\hline Emex australis Steinh. & 6.3 & 5.5 & 11.8 \\
\hline Hypochoeris glabra L. & 5.6 & 4.4 & 10.0 \\
\hline Coronopus didymus (L.) Sm. & 5.9 & 4.0 & 9.9 \\
\hline Capsella bursa-pastoris (L.) Medik. & 5.9 & 3.4 & 9.3 \\
\hline Erodium moschatum (L.) L'Hér. & 5.6 & 1.9 & 7.5 \\
\hline Cerastuim capense Sond. & 5.2 & 1.9 & 7.1 \\
\hline Anagallis arvensis $\mathrm{L}$. & 4.9 & 2.1 & 7.0 \\
\hline Oxalis pes-caprae $\mathrm{L}$. & 5.2 & 1.8 & 7.0 \\
\hline Rumex crispus $\mathrm{L}$. & 4.9 & 1.6 & 6.5 \\
\hline Lolium multiflorum Lam. & 3.5 & 1.8 & 5.2 \\
\hline Malva parviflora $\mathrm{L}$. & 3.5 & 0.8 & 4.2 \\
\hline Plantago lanceolata $\mathrm{L}$. & 2.8 & 0.8 & 3.5 \\
\hline Lamium amplexicaule $\mathrm{L}$. & 1.0 & 0.5 & 1.5 \\
\hline
\end{tabular}

Table 5 Botanical name, frequency, relative density and relative abundance of annual summer weeds observed at George during a preceding assessment

\begin{tabular}{|c|c|c|c|}
\hline & Frequency & Relative & Relative \\
\hline Botanical name & $\%$ & density \% & abundance \\
\hline Cyperus esculentus $\mathrm{L}$. & 8.8 & 66.1 & 74.8 \\
\hline Galinsoga parviflora Cav. & 7.7 & 3.0 & 10.7 \\
\hline Polygonum aviculare $\mathrm{L}$. & 6.9 & 3.5 & 10.5 \\
\hline Conyza bonariensis (L.) Cronq. & 7.3 & 2.9 & 10.2 \\
\hline Amaranthus hybridus L. & 6.9 & 2.5 & 9.5 \\
\hline Brachiaria eruciformis (Sm.) Griseb. & 6.6 & 2.6 & 9.2 \\
\hline Chenopodium album $\mathrm{L}$. & 6.2 & 2.8 & 9.0 \\
\hline Echium plantagineum $\mathrm{L}$. & 6.2 & 2.0 & 8.2 \\
\hline Digitaria sanguinalis (L.) Scop. & 5.5 & 2.3 & 7.8 \\
\hline Datura stramonium $\mathrm{L}$. & 5.8 & 1.8 & 7.6 \\
\hline Portulaca oleracea $\mathrm{L}$. & 5.5 & 1.5 & 6.9 \\
\hline Bidens pilosa $\mathrm{L}$. & 5.1 & 1.7 & 6.8 \\
\hline Lactuca serriola $\mathrm{L}$. & 5.1 & 1.6 & 6.7 \\
\hline Gnaphalium subfalcatum Cabrera. & 4.7 & 2.0 & 6.7 \\
\hline Eleusine coracana (L.) Gaertn. & 4.4 & 1.9 & 6.3 \\
\hline Nicandra physalodes (L.) Gaertn. & 3.3 & 0.9 & 4.2 \\
\hline Sonchus asper (L.) Hill & 1.8 & 0.4 & 2.2 \\
\hline Oenothera parodiana Munz. subsp. parodiana & 1.1 & 0.2 & 1.3 \\
\hline Tribulus terrestris $\mathrm{L}$. & 1.1 & 0.2 & 1.3 \\
\hline
\end{tabular}


Table 6 Percentage relative winter weed density observed at George subsequent to the application of treatments from $2015-2017$

\begin{tabular}{|c|c|c|c|c|c|c|c|c|}
\hline \multirow[b]{2}{*}{ Botanical name } & \multicolumn{8}{|c|}{ Treatment* } \\
\hline & $\mathrm{SCB}$ & $\mathrm{CSC}$ & SSB & CBS & $\mathrm{BSC}$ & SBC & $\mathrm{BCB}$ & $\mathrm{C}$ \\
\hline Arctotheca calendula (L.) Levyns & 0.0 & 0.0 & 0.0 & 0.0 & 0.9 & 0.0 & 4.8 & 3.5 \\
\hline Anagallis arvensis $\mathrm{L}$. & 32.3 & 26.2 & 34.8 & 36.0 & 30.7 & 27.1 & 25.9 & 15.1 \\
\hline Capsella bursa-pastoris (L.) Medik. & 0.0 & 0.0 & 0.0 & 0.0 & 2.6 & 1.6 & 2.7 & 2.1 \\
\hline Cerastuim capense Sond. & 1.6 & 0.0 & 0.0 & 0.0 & 0.9 & 7.0 & 2.7 & 6.8 \\
\hline Coronopus didymus (L.) Sm. & 0.0 & 0.0 & 2.9 & 4.0 & 3.5 & 3.1 & 3.4 & 5.0 \\
\hline Emex australis Steinh. & 0.0 & 0.0 & 0.0 & 0.0 & 0.0 & 0.0 & 0.0 & 0.0 \\
\hline Erodium moschatum (L.) L'Hér. & 3.2 & 1.2 & 0.0 & 0.0 & 0.9 & 0.0 & 0.0 & 0.0 \\
\hline Fumaria muralis W.D.J. Koch. & 0.0 & 0.0 & 4.3 & 7.0 & 8.8 & 10.1 & 11.6 & 2.7 \\
\hline Hypochoeris glabra L. & 0.0 & 0.0 & 0.0 & 0.0 & 0.0 & 2.3 & 2.0 & 5.0 \\
\hline Lamium amplexicaule $\mathrm{L}$. & 9.7 & 34.5 & 5.8 & 7.0 & 3.5 & 6.2 & 12.9 & 7.9 \\
\hline Lolium multiflorum Lam. & 0.0 & 0.0 & 0.0 & 0.0 & 0.0 & 0.8 & 0.7 & 0.6 \\
\hline Malva parviflora $\mathrm{L}$. & 0.0 & 0.0 & 0.0 & 0.0 & 0.0 & 2.3 & 0.0 & 0.0 \\
\hline Oxalis pes-caprae $\mathrm{L}$. & 11.3 & 3.6 & 2.9 & 2.0 & 1.8 & 5.4 & 4.8 & 2.5 \\
\hline Plantago lanceolata $\mathrm{L}$. & 0.0 & 1.2 & 1.4 & 3.0 & 0.0 & 1.6 & 0.7 & 2.7 \\
\hline Poa aпnиа $\mathrm{L}$. & 21.0 & 15.5 & 13.0 & 8.0 & 8.8 & 8.5 & 8.8 & 4.6 \\
\hline Raphanus raphanistrum $\mathrm{L}$. & 1.6 & 1.2 & 2.9 & 0.0 & 0.0 & 0.8 & 2.0 & 6.6 \\
\hline Rumex crispus L. & 0.0 & 1.2 & 8.7 & 10.0 & 27.2 & 0.0 & 2.7 & 20.7 \\
\hline Spergula arvensis L. & 11.3 & 14.3 & 23.2 & 22.0 & 4.4 & 16.3 & 7.5 & 11.8 \\
\hline Stellaria media (L.) Vill. & 8.1 & 1.2 & 0.0 & 1.0 & 6.1 & 7.0 & 6.8 & 2.3 \\
\hline
\end{tabular}

${ }^{*} \mathrm{SCB}=$ saia oats-cereal rye-Braco mustard+Vetch, $\mathrm{CSC}=$ cereal rye-saia oats-cereal rye+vetch, $\mathrm{SSB}=$ saia oats + lupine-cereal rye+serradella-Braco mustard, $\mathrm{CBS}=$ cereal rye+serradella-Braco mustard-saia oats+lupine, $\mathrm{BSC}=$ Braco mustard-saia-oats + lupine-cereal rye+serradella, $\mathrm{SBC}=$ saia oats+serradella-Braco mustard+lupine-cereal rye+lupine, $\mathrm{BCB}=$ Braco mustard+lupine-cereal rye+vetch-Braco mustard+lupine and $\mathrm{C}=$ untreated control.

Common henbit (Lamium amplexicaule L.) showed the fourth highest relative density of $3.5 \%$ or greater, across all treatments (Table 6). This was substantially higher than values recorded during the preceding weed assessment and a clear indication that practices like zero-tillage, smother cropping with legumes, brush cutting and rotary mowing with flail heads created ideal conditions for the growth of this weed. It is highly likely that low light intensity and a particular micro-climate under the leaf canopy of crops created a growth niche that favoured common henbit.

The fifth most important weed in terms of relative winter weed density was Cape sorrel (O. pes-caprae L.), which maintained a presence of $1.8 \%$ or greater in the weed community, across all treatments. In the case of treatment $\mathrm{SCB}$, this increased to $11.3 \%$ of the weed community (Table 6), most likely due to water-saturated soil conditions, which improved growing conditions for Cape sorrel.

At the final weed assessment, twin cress (Coronopus didymus (L.) $\mathrm{Sm}$.) and wall fumitory (F. muralis W.D.J. Koch.), was not observed as it did not emerge and was absent in plots under treatments SCB and CSC (Table 6). This could have been the result of fierce competition by common henbit (L. amplexicaule L.), Cape sorrel ( $O$. pes-caprae L.), corn spurry (S. arvensis L.) and annual blue grass ( $P$. annua $\mathrm{L}$.) which all had the substantial presence of over $3 \%$ in weed communities of both treatments SCB and CSC.

Surprisingly, devil's thorn (E. australis Steinh.) which had a relative density of $5.5 \%$ when the preceding assessment was conducted did not emerge during the final weed assessment (Table 6). Besides, weeds like wild radish $(<3 \%$ in treated plots, but $6.6 \%$ in the control) and Italian ryegrass (Lolium multiflorum Lam.) $(<1 \%)$, which normally dominate the weed spectrum in wheat-producing areas, at this locality struggled to contribute substantially to the weed community.

The unusually high percentage relative weed densities of particular species shown by some treatments were most probably the result of uncontrolled seed shedding, which led to severe secondary infestations in successive years. This phenomenon is illustrated in Table 6 where it is evident that the high values for common henbit 
(L. amplexicaule L.) in treatment CSC (34.5\%) and curly dock (Rumex crispus L.) in treatment BSC (27.2\%) generally, are not in line with other values for both species.

\subsection{Final summer weed density}

The most important weed in terms of relative summer weed density was yellow nut sedge ( $C$. esculentes $\mathrm{L}$.), which maintained a presence of $14.4 \%$ or more, across all treatments. It achieved the greatest value of $47.6 \%$ of the weed community in treatment CSC (Table 7). Common purslane (Portulaca oleraceae L.) was the second most important weed in terms of relative summer weed density in the community and maintained a presence of $5.6 \%$ or greater across all treatments (Table 7). In treatments SCB, CSC, and SSB, this increased to above $20 \%$. Flax-leaf fleabane (C. bonariensis (L.) Cronq.) showed the third-highest relative summer weed density of $2.9 \%$ or greater, across all treatments. The lowest proportional value for this weed was observed in treatment SSB (Table 7).
Summer weeds that were not recorded at all during the final assessments included Paterson's curse (E. plantagineum L.), evening primrose (Oenothera parodiana Munz. subsp. parodiana), devil's thorn (Tribulus terrestris L.) and goose grass (Eleusine coracana (L.) Gaertn.). This could have been the result of unfavourable growing conditions caused by fierce competition by flax-leaf fleabane (C. bonariensis (L.) Cronq.), common purslane ( $P$. oleraceae L.), and yellow nut sedge (C. esculentes L.) all of which maintained a strong presence in summer weed communities with relative densities of $2.9 \%$ or greater, across all treatments (Table 7).

The percentage relative weed density of several winter annual weed species increased substantially when compared to the assessment preceding the field experiment. For instance, the final relative density of scarlet pimpernel (A. arvensis L.) in the weed community was above $25 \%$ across all treated plots, compared to $2.6 \%$ in the preceding assessment. Also, common henbit

Table 7 Percentage relative summer weed density observed at George subsequent to the application of treatments from 2015 -2017

\begin{tabular}{|c|c|c|c|c|c|c|c|c|}
\hline \multirow[b]{2}{*}{ Botanical name } & \multicolumn{8}{|c|}{ Treatment* } \\
\hline & $\mathrm{SCB}$ & CSC & SSB & CBS & BSC & SBC & $\mathrm{BCB}$ & $\mathrm{C}$ \\
\hline Amaranthus hybridus L. & 0.0 & 0.0 & 0.0 & 0.0 & 1.8 & 1.0 & 3.1 & 5.9 \\
\hline Bidens pilosa $\mathrm{L}$. & 0.0 & 0.0 & 0.0 & 0.0 & 5.3 & 1.0 & 2.1 & 0.0 \\
\hline Brachiaria eruciformis (Sm.) Griseb. & 4.3 & 0.0 & 0.0 & 0.0 & 0.0 & 4.8 & 8.3 & 0.0 \\
\hline Chenopodium album $\mathrm{L}$. & 0.0 & 0.0 & 0.0 & 12.7 & 14.0 & 3.8 & 4.2 & 1.9 \\
\hline Conyza bonariensis (L.) Cronq. & 4.3 & 4.8 & 2.9 & 7.3 & 17.5 & 22.1 & 3.1 & 3.3 \\
\hline Cyperus esculentus $\mathrm{L}$. & 43.5 & 47.6 & 47.1 & 25.5 & 29.8 & 14.4 & 22.9 & 46.8 \\
\hline Datura stramonium $\mathrm{L}$. & 0.0 & 0.0 & 0.0 & 0.0 & 0.0 & 4.8 & 3.1 & 0.0 \\
\hline Digitaria sanguinalis (L.) Scop. & 0.0 & 0.0 & 0.0 & 0.0 & 7.0 & 17.3 & 21.9 & 3.7 \\
\hline Echium plantagineum $\mathrm{L}$. & 0.0 & 0.0 & 0.0 & 0.0 & 0.0 & 0.0 & 0.0 & 0.0 \\
\hline Eleusine coracana (L.) Gaertn. & 0.0 & 0.0 & 0.0 & 0.0 & 0.0 & 0.0 & 0.0 & 0.0 \\
\hline Galinsoga parviflora Cav. & 15.2 & 9.5 & 8.8 & 0.0 & 1.8 & 0.0 & 0.0 & 0.0 \\
\hline Gnaphalium subfalcatum Cabrera. & 0.0 & 0.0 & 0.0 & 0.0 & 0.0 & 0.0 & 4.2 & 0.0 \\
\hline Lactuca serriola $\mathrm{L}$. & 0.0 & 0.0 & 0.0 & 0.0 & 0.0 & 0.0 & 3.1 & 0.0 \\
\hline Nicandra physalodes (L.) Gaertn. & 0.0 & 0.0 & 0.0 & 7.3 & 0.0 & 11.5 & 0.0 & 20.8 \\
\hline Oenothera parodiana Munz. subsp. parodiana & 0.0 & 0.0 & 0.0 & 0.0 & 0.0 & 0.0 & 0.0 & 0.0 \\
\hline Polygonum aviculare $\mathrm{L}$. & 0.0 & 7.1 & 20.6 & 38.2 & 10.5 & 9.6 & 10.4 & 11.9 \\
\hline Portulaca oleracea $\mathrm{L}$. & 32.6 & 31.0 & 20.6 & 9.1 & 7.0 & 9.6 & 10.4 & 5.6 \\
\hline Sonchus asper (L.) Hill & 0.0 & 0.0 & 0.0 & 0.0 & 0.0 & 0.0 & 3.1 & 0.0 \\
\hline Tribulus terrestris $\mathrm{L}$. & 0.0 & 0.0 & 0.0 & 0.0 & 0.0 & 0.0 & 0.0 & 0.0 \\
\hline
\end{tabular}

$* \mathrm{SCB}=$ saia oats-cereal rye-Braco mustard+Vetch, $\mathrm{CSC}=$ cereal rye-saia oats-cereal rye+vetch, $\mathrm{SSB}=$ saia oats+lupine-cereal rye+serradellaBraco mustard, $\mathrm{CBS}=$ cereal rye + serradella-Braco mustard-saia oats + lupine, $\mathrm{BSC}=$ Braco mustard-saia-oats + lupine-cereal rye + serradella, $\mathrm{SBC}=$ saia oats + serradella-Braco mustard+lupine-cereal rye+lupine, $\mathrm{BCB}=$ Braco mustard+lupine-cereal rye+vetch-Braco mustard+lupine and $\mathrm{C}=$ untreated control. 
(L. amplexicaule L.) increased its relative density in the weed community from the preceding $0.5 \%$ (Table 4 ) to finally record $12.9 \%$ in treatment BCB (Table 6). This is apart from treatment $\mathrm{CSC}$ at $34.5 \%$, which is abnormally high and might have been caused by a secondary infestation. Similarly, at the preceding assessment Cape sorrel (O. pes-caprae L.) showed a relative density of $1.8 \%$ (Table 4 ), but a final relative density of $11.3 \%$ in treatment SCB (Table 6). Subsequent to a preceding relative density of $6.4 \%$ in the weed community, results for corn spurry (S. arvensis L.) showed a final value of $23.2 \%$ in treatment SSB (Table 6). The relative density of annual blue grass ( $P$. annua $\mathrm{L}$.) showed a decrease from $26.6 \%$ at the preceding assessment to record a final relative density of $21.0 \%$ after treatment SCB (Table 6).

Summer annual weed species also showed substantial increases in percentage relative densities when compared to the preceding weed assessment. Common purslane ( $P$. oleraceae L.) increased its relative density in the weed community from $1.5 \%$ (Table 5 ) in the preceding weed assessment to finally achieve $32.6 \%$ in treatment SCB (Table 7). For flax-leaf fleabane ( $C$. bonariensis (L.) Cronq.) a relative density of $2.9 \%$ in the preceding assessment (Table 5), and a final relative density of $22.1 \%$ in treatment SBC (Table 7) were recorded. By contrast, the relative density of yellow nut sedge (C. esculentes L.) showed a decrease from $66.1 \%$ in the preceding assessment (Table 5) to record a final relative density of $14.4 \%$ subsequent to treatment SBC, providing further proof of the impact of these integrated non-chemical weed suppressive strategies on weeds. Compared to other treatments, it is obvious that treatment $\mathrm{SBC}$ provided the greatest suppression of yellow nut sedge $(C$ esculentes L.) at this locality.

\section{Discussion and conclusions}

The relative densities obtained in this study for both winter and summer annuals indicate that the life cycle and phenology of some of these weeds may account for their persistence despite control efforts (McCully et al., 1991). The increasing relative densities of weed species belonging to the Asteraceae plant family correspond with findings by Van Acker et al. (2000) who also reported no increases in species from Brassicaceae or the numbers of species in all other weed families. Contrasting sharply in this study, species from the families Primulaceae, Lamiaceae, Oxalidaceae, Caryophyllaceae, Portulacaceae, and Asteraceae substantially increased their respective relative densities.

Generally, results correspond to a study by Ruisi et al. (2015) which showed that weed occurrence, composition, and density are reflections of past and present agricultural practices. Furthermore, results indicated that weed community composition at George varies in association with different cropping practices. Weed communities found under different cropping practices inevitably vary in their competitive potential. A further consideration by
McCully et al. (1991) is that weed density does not take into consideration the size of the weeds. Some weeds are short, small, and grow well below the crop leaf canopy and probably are of low competitive potential (MacLaren et al., 2019). Added to this are other species with high frequencies, densities and relative abundances, but pose no threat to crop harvesting or competition for sunlight. The main threat would arise from competition for nutrients and water. However, McCully et al. (1991) observed that taller crops with tap roots appear to withstand the growth of these weeds below their canopy without yield loss.

The response of many weed species in the current study is following earlier reports. For example, the very low relative density of Italian ryegrass (L. multiflorum L.) can to a large extend be attributed to the practice of zero-tillage and limited herbicide use (MacLaren et al., 2019). Results for Conyza spp., twin cress (C. didymus (L.) Sm.) and shepherd's purse (Capsella bursa-pastoris L. Medik.) agree with findings by Derksen et al. (1993) that infestations of these species are strongly associated with zero-tillage. Recent findings by MacLaren et al. (2019) showed that factors such as treatment with herbicides and drier conditions were associated with a higher abundance of Lolium spp. Also, mown plots in wetter areas were associated with the native weed Cape sorrel (O. pes-caprae L.) (MacLaren et al., 2019). Furthermore, MacLaren et al. (2019) reported that musk heron's bill (Erodium moschatum (L.) L'Her.) and wild radish ( $R$. raphanistrum L.) showed an association with tilled sites. It may be assumed that when the practice of zero-tillage is utilized, reduced densities of both aforementioned weed species may be observed. Moreover, according to (MacLaren et al., 2019) mowing permitted a higher diversity and abundance of weeds, including the occurrence of more native weeds. This suggests that the best approach to reach the competitive potential of a weed community is by utilizing integrated management practices, which include brush cutting and rotary mowing with flail heads.

Many weed species such as white goose foot (C. album L.) have their germination associated with crop sowing date (Gunton et al., 2011) and can tolerate continuous disturbance regimes. A typical disturbance-tolerance strategy is the steady germination ability of weed seeds throughout the cultivation period (Fried et al., 2012). Nagy et al. (2018) reported that the sowing season was an important driver of weed composition and Fried et al. (2012) concurred that the presence of multiple crops and cropping times may considerably increase the regional weed species pool. The importance of this is that a larger weed species pool improves weed species richness, which leads to more diversity and interspecies competition in weed communities. MacLaren et al. (2019) concluded that consistently trying to remove all weeds from farmland is unsustainable. Instead, pathways must be identified to reduce weed control efforts and to integrate the positive functions of weeds into agro-ecosystems. 
Farooq et al. (2011) elaborated that conservation agriculture, based on minimum soil disturbance and permanent soil cover, is an alternative approach for managing agro-ecosystems, which enhances crop production, resource cycling, and environmental safety, even if weed control is one of the most difficult challenges in crop management. Therefore, studies evaluating cropping systems are essential for gaining insight into their effects on weed floristic composition and species diversity (Halde et al., 2015). In particular, long-term field experiments are important for evaluating changes in weed flora composition (Ruisi et al., 2015). Furthermore, at this locality, research on the role of allelopathy in smother cropping and mulching, as well as all aspects of cultivated ecosystems (Ferreira \& Reinhardt, 2016), would provide insight and improve decision making regarding weed management and sustainable agriculture.

Information on the floristic composition and abundance is an important component of weed communities and for decisionmaking regarding weed management. Persistent and troublesome weed communities may be managed non-chemically with smother cropping strategies by integrating zero-tillage, legume-based crop mixtures, brush cutting and rotary mowing with flail heads to produce a biomass mulch. This can promote more desirable weed communities and suppress noxious weeds such as yellow nut sedge in the context of local conditions. Finally, this study will assist agriculturalists to understand and manage the current weed vegetation and also serve as a baseline study for future weed research in this region.

\section{Acknowledgements}

Support and funding for this research was provided by the directorate: Plant Sciences, Programme: Research and Technology Development, Western Cape Department of Agriculture. Technical assistance provided by the Department of Correctional Services, George, and colleagues Z Sedeman and H Gerber, is highly appreciated.

\section{Conflict of interests}

The author declares no conflict of interests.

\section{References}

Andersson TN, Milberg P (1998) Weed flora and the relative importance of site, crop, crop rotation, and nitrogen. Weed Science 46: $30-38$.

Campiglia E, Radicetti E, Mancinelli R (2018) Floristic composition and species diversity of weed community after 10 years of different cropping systems and soil tillage in a Mediterranean environment. Weed Research 58: 273-283.
Cicuzza D, Clough Y, Tjitrosoedirdjo SS, Kessler M (2012) Responses of terrestrial herb assemblages to weeding and fertilization in cacao agroforests in Indonesia. Agroforestry Systems 85: 75-83.

Derksen DA, Lafond GP, Thomas AG, John EA (1993) Impact of agronomic practices on weed communities - tillage systems. Weed Science 41: 409-417.

Doucet C, Weaver SE, Hamill AS, Zhang J (1999) Separating the effects of crop rotation from weed management on weed density and diversity. Weed Science 47:729-735.

Farooq M, Flower KC, Jabran K, Wahid A, Siddique KHM (2011) Crop yield and weed management in rainfed conservation agriculture. Soil Tillage Research 117:172-183.

Ferrara G, Mazzeo A, Matarrese A (2015) Soil management systems: effects on soil properties and weed flora. South African Journal of Enology and Viticulture36: 11-20.

Ferreira MI, Reinhardt CF (2016) Allelopathic weed suppression in agroecosystems: A review of theories and practices. African Journal of Agricultural Research 11: 450-459.

Ferreira MI, Reinhardt CF (2010) Field assessment of crop residues for allelopathic effects on both crops and weeds. Agronomy Journal 102:1593-1600.

Fried G, Kazakou E, Gaba S (2012) Trajectories of weed communities explained by traits associated with species' response to management practices. Agriculture, Ecosystems and Environment 158: 147-155.

Gaba S, Perronne R, Fried G (2017) Response and effect traits of arable weeds in agro-ecosystems: a review of current knowledge. Weed Research 57: 123-147.

Garcia RR, Mifiarro M (2014) Role of floral resources in the conservation of pollinator communities in cider-apple orchards. Agriculture, Ecosystems and Environment 183: 118-126.

Garnier E, Nava ML (2012) A trait-based approach to comparative functional plant ecology: concepts, methods and applications for agroecology. A review. Agronomy for Sustainable Development32: 365-399.

Gunton RM, Petit S, Gaba S (2011) Functional traits relating arable weed communities to crop characteristics. Journal of Vegetation Science 22: 541-550.

Halde C, Bamford KC, Entz MH (2015) Crop agronomic performance under a six year continuous organic no-till system and other tilled and conventionally-managed systems in the Northern 
Great Plains of Canada. Agriculture, Ecosystems \&Environment 213:121-130.

Juarez-Escario A, Conesa JA, Solé-Senan XO (2017) Management as a driver of functional patterns and alien species prominence in weed communities of irrigated orchards in Mediterranean areas. Agriculture, Ecosystems\& Environment 249: 247-255.

Kropff MJ, Weaver SE, Smits MA (1992) Use of ecophysiological models for crop-weed interference: relations amongst weed density relative time of weed emergence, relative leaf area and yield loss. Weed Science 40: 296-301.

Mas MT, Poggio SL, Verdu AMC (2007) Weed community structure of mandarin orchards under conventional and integrated management in northern Spain. Agriculture, Ecosystems\& Environment 119: 305-310.

MacLaren C, Bennett J, Dehnen-Schmutz K (2019) Management practices influence the competitive potential of weed communities and their value to biodiversity in South African vineyards. Weed Research 59: 93-106.

McCully KV, Sampson MG, Watson AK (1991)Weed survey of Nova Scotia low bush blueberry (Vaccinium angustifolium) fields. Weed Science39: 180-185.

Milberg P, Hallgren E, Palmer MW (2000) lnter annual variation in weed biomass on arable land in Sweden. Weed Research40:311-321.

Moeini MM, Baghestani MA, Mashhadi HR (2008) Introducing an abundance index for assessing weed flora in survey studies. Weed Biology and Management 8: 172-180.

Nagy K, Lengyel A, Kovács A, Türei D, Csergö AM Pinke G (2018) Weed species composition of small-scale farmlands bears a strong crop-related and environmental signature. Weed Research 58: $46-56$
Linares J, Scholberg J, Boote K, Chase CA, Ferguson JJ McSorley $\mathrm{R}$ (2008) Use of the cover crop weed index to evaluate weed suppression by cover crops in organic citrus orchards. HortScience 43: $27-34$.

Navas ML (2012) Trait-based approaches to unravelling the assembly of weed communities and their impact on agro-ecosystem functioning. Weed Research52: 479-488.

Ruisis P, Frangipane B, Amato G (2015) Weed seed bank size and composition in a long term tillage and crop sequence experiment. Weed Research 55:320-328.

Shrestha A, Knezevic SZ, Roy RC, Ball-Coelho BR, Swanton CJ (2001) Effect of tillage, cover crop and crop rotation on the composition of weed flora in a sandy soil. Weed Research 42: 7687.

Swanepoel PA, Du Preez CC, Botha PR, Snyman HA (2015) A critical view on the soil fertility status of minimum-till kikuyuryegrass pastures in South Africa. African Journal of Range \& Forage Science32: 113-124.

Soil Classification Working Group (1991) Soil classification: a taxonomic system for South Africa. Memoirs on the Agricultural Natural Resources of South Africa no. 15. Department of Agricultural Development: Pretoria.

Soil Survey Staff (2003) Keys to soil taxonomy. USA Department of Agriculture: Washington, DC

Van Acker RC, Thomas AG, Leeson JY, Knezevic SZ, Frick BL (2000) Comparison of weed communities in Manitoba ecoregions and crops. Canadian Journal of Plant Science 80: 963-972.

Wedryk S, Cardina J (2012) Smother crop mixtures for Canada thistle (Cirsium arvense) suppression in organic transition. Weed Science 60: 618-623. 